\title{
New geophysical and geological mapping of the eastern Baffin Bay region, offshore West Greenland
}

\author{
Ulrik Gregersen, Paul C. Knutz and John R. Hopper
}

The Geological Survey of Denmark and Greenland has carried out a detailed mapping project in the eastern Baffin Bay region covering c. $200000 \mathrm{~km}^{2}$ (Fig. 1). The purpose of the study was to update the previous mapping by using the most recent data and provide an improved basis for evaluation of the geological development and hydrocarbon potential of the region. After licensing rounds in 2007-2008 and 2010 considerable new geophysical and geological data were acquired in the region, and the extensive database now includes more than $100000 \mathrm{~km} \mathrm{2D}$ seismic data and a number of wells (Fig. 1). The results of the work are summarised below and suggest deep basins and large ridges with complex structures.

\section{Geological setting}

In areas along the West Greenland continental margin, a number of basins with Proterozoic, Cretaceous and Cenozoic sedimentary successions have been identified (e.g., Dawes 1997; Dam et al. 2009; Rolle 1985). A number of rifted basins with large structural highs are interpreted to have developed in the east Baffin Bay region (Whittaker $e t$ al. 1997; Gregersen et al. 2013). During the Paleocene and Eocene, oceanic crust developed in central Baffin Bay and the Cretaceous rifted continental margin of West Greenland was separated from eastern Canada (Oakey \& Chalmers 2012). The large-scale movements between Greenland and Canada generated new structures during the Palaeogene and reactivated faults within Cretaceous basins.

\section{Results}

The study included seven sub-projects: (1) seismic interpretation and mapping; (2) well correlation; (3) biostratigraphy; (4) seismic facies analysis and seismic inversion; (5) overview of source rocks; (6) maturity modelling; and (7) structural development. This paper describes some key results from the seismic interpretation and structural development. Interpretation of horizons and units were carried out with Schlumberger Petrel $^{\odot}$ software and included data from wells, seismic surveys, gravity surveys and magnetic surveys. Additional data from seabed sampling and outcrops in the region were used for geological interpretation and as analogues. A robust framework was established with fourteen seismic stratigraphic horizons (A1-Hx) and eleven mega-units $(\mathrm{A}-\mathrm{H})$. Seismic cross-sections show deep, rifted basins separated by large structural highs (Fig. 2). The lateral extends and topography of the basins and structures are outlined in depth-structure maps (Fig. 3).

In the Kap York Basin (Fig. 4), the upper part of megaunit $\mathrm{H}$ can be correlated to parts of a $4.6 \mathrm{~km} / \mathrm{sec}$. TWT velocity zone from refraction seismic lines of Reid \& Jackson (1997). They interpreted this zone to include Thule Supergroup sedimentary rocks, which crop out north of the study area (Dawes 1997). Thus the upper part of mega-unit $\mathrm{H}$ below horizon $\mathrm{H} 1$ (Fig. 2) probably includes sedimentary rocks with some analogues to the Thule Supergroup. Seismic interpretation suggests that some of the

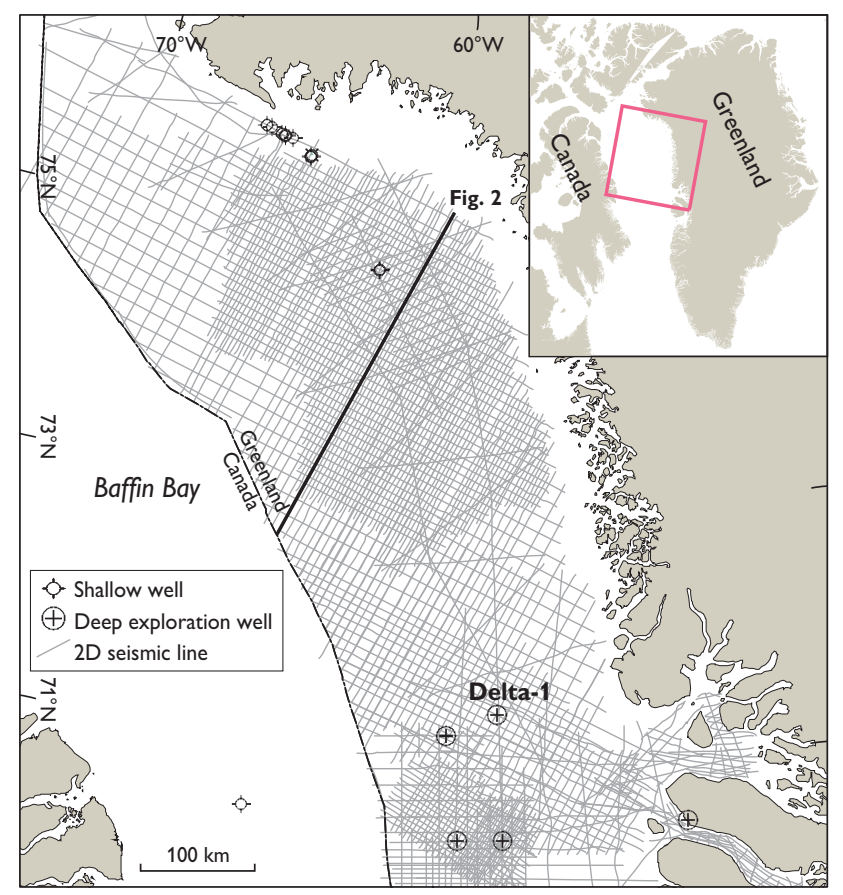

Fig. 1. Map of the study area in eastern Baffin Bay with 2D seismic data used and the location of shallow and deep exploration wells. Location of the seismic line of Fig. 2 is also shown. 


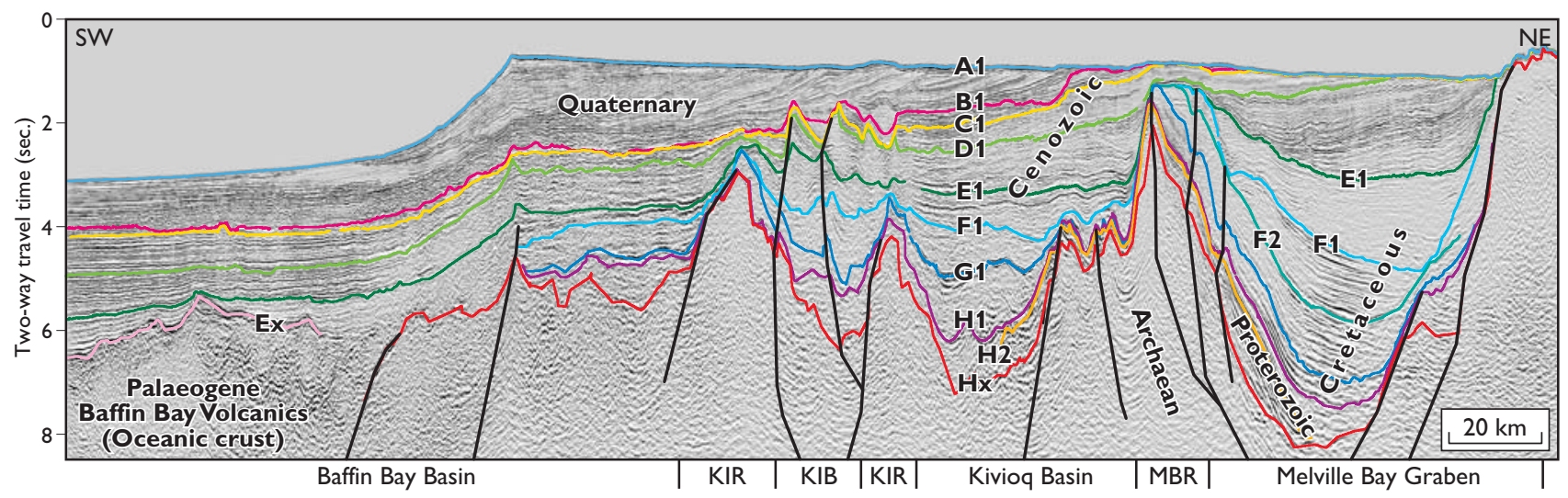

Fig. 2. Seismic line NE-SW across the eastern Baffin Bay region showing deep basins and large structures. The horizon boundaries of the seismic mega-units A-H are shown by coloured horizons from A1 to $\mathrm{Hx}$ and likely ages are shown. Note that some of the major deep-seated faults continue nearly vertically upwards through parts of the Cenozoic section indicating late compressional faulting. The names of the main structural elements are shown below the line and are from SW to NE: Baffin Bay Basin. KIR: Kivioq Ridge. KIB: Kivioq Basin. MBR: Melville Bay Ridge. Melville Bay Graben (Fig. 4). The seismic line is courtesy of TGS-NOPEC Geophysical Company ASA. Location of the seismic line is shown in Fig. 1.

wedge-shaped units in mega-unit $\mathrm{H}$ (Fig. 2) were probably formed by extension during the Proterozoic.

Sedimentary successions in the Baffin Bay may also resemble those from the Nuussuaq Basin, where Cretaceous nearshore to deltaic sandy deposits were documented (Dam et al. 2009). Seismic interpretation below horizon F1 (mega-unit F) shows prograding-aggrading clinoforms and troughs or channels possibly from deltaic systems (Gregersen et al. 2013).

During parts of the Late Cretaceous, relative tectonic quiescence prevailed and thick uniform units were deposited in the basins. Marine mudstone deposits with suggested source-rock intervals and oil seeps were recovered from both West Greenland (Bojesen-Koefoed et al. 1999) and northern East Canadian islands (MacLean \& Williams 1983; Brent et al. 2013). Within the mapped basins, these marine mudstones may be analogous to deposits in mega-units $\mathrm{E}$ and F, between horizons E1 and G1 (Fig. 2). Extensional faulting occurred during the Late Cretaceous to earliest $\mathrm{Pa}$ leocene by local rifting in the Nuussuaq Basin (Dam et al. 2009) and locally in a few other places in the region.

In north-eastern Baffin Bay, major Cretaceous rift basins trend SE-NW and are located east of the Kivioq Ridge (Fig. 4). West of the Kivioq Ridge, extensive volcanic areas have been mapped primarily from seismic reflection and magnetic anomaly data (Fig. 4). Studies with refraction seismic data (Damm 2010; Suckro et al. 2012; Altenbernd et al. 2014) showed oceanic crust in the eastern part of the Baffin Bay Basin. Seismic facies analyses combined with interpretation of magnetic data in the present study and in Gregersen et al. (2013) outline the eastern boundary of the oceanic crust (also named Baffin Bay Volcanics) at nearly the same location (Figs 2, 4). The oceanic crust developed as Greenland and its rifted margin separated from Canada during the Paleocene and Eocene (Oakey \& Chalmers 2012). The north-east and northward movements of Greenland's rifted basins caused compression-related

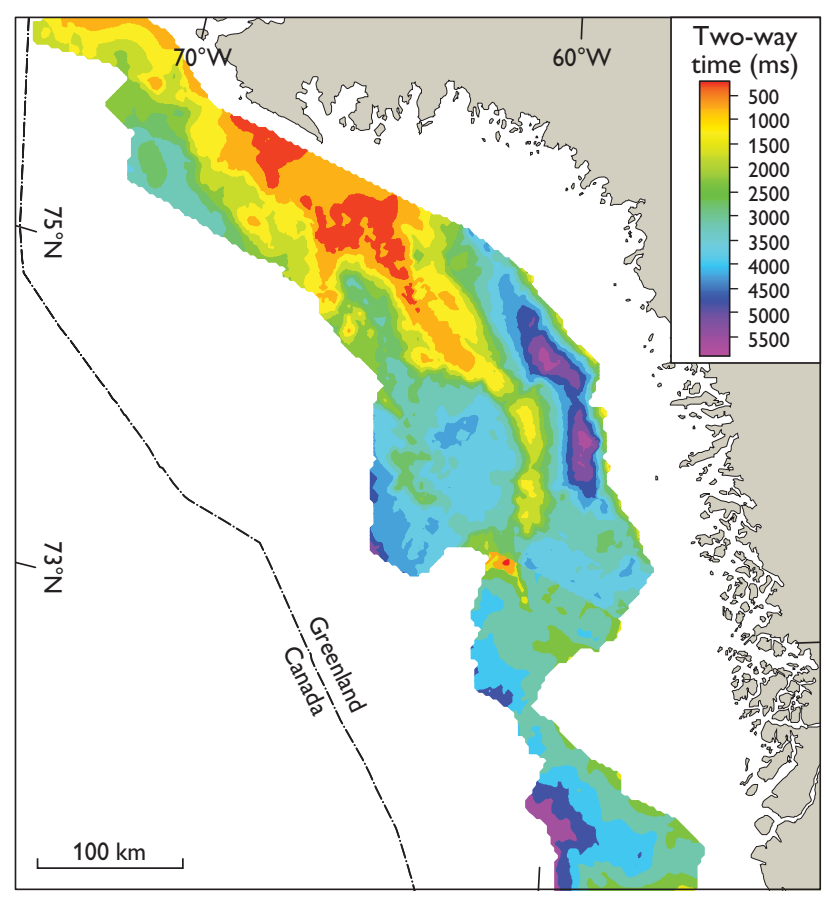

Fig. 3. Depth-structure map of horizon F1 with two-way travel time. This level is not drilled in the region but interpretation suggests that the horizon may be of a Late Cretaceous (Campanian?) age. The map illustrates the outline of large structures and basins of eastern Baffin Bay. 
Fig. 4. Structural elements map of eastern Baffin Bay. The extent of the Canadian part of the Baffin Bay oceanic crust is from Oakey \& Chalmers (2012).

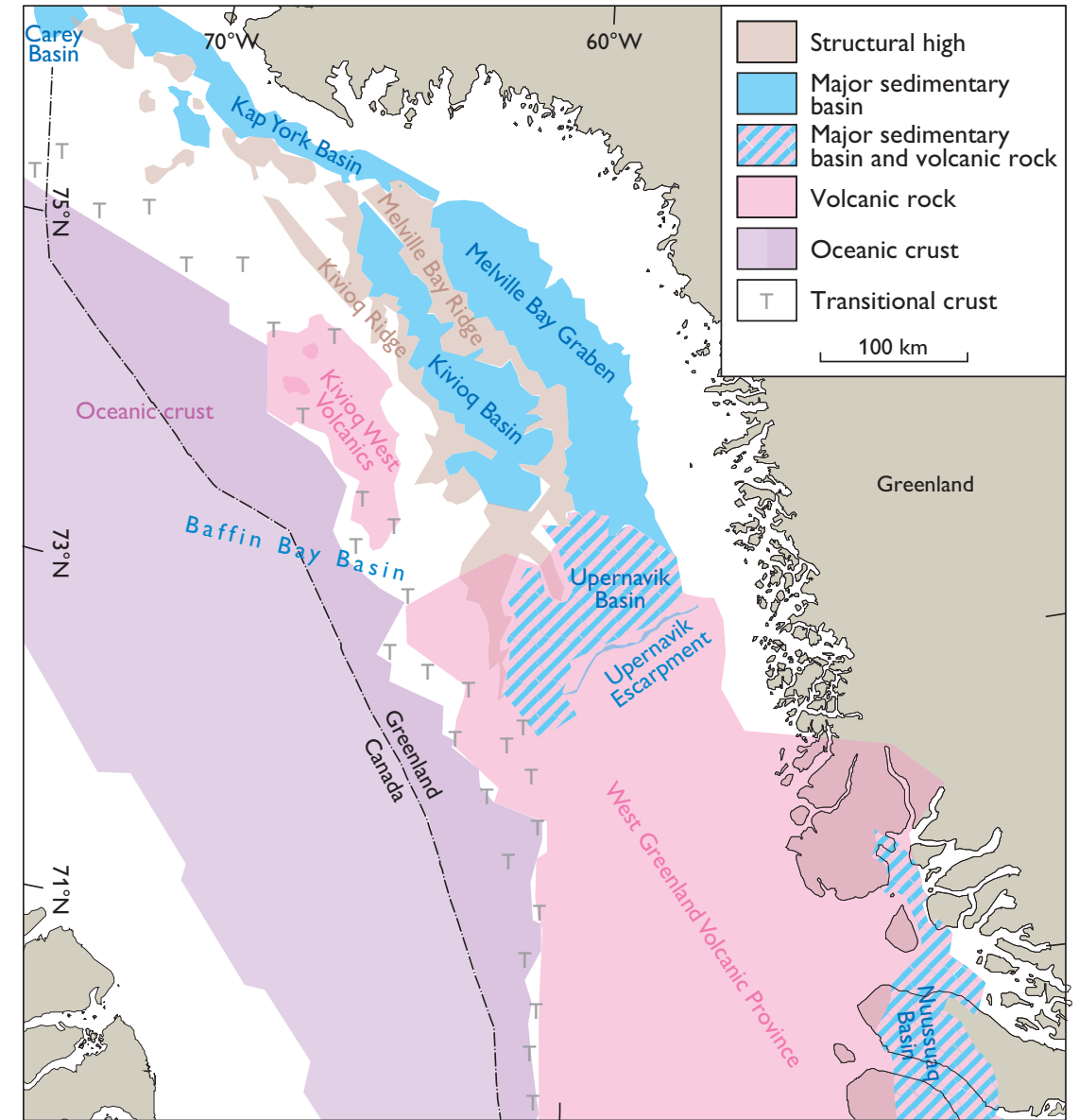

tectonism with inversion, transtension and thrust faults developing (Fig. 2). The Palaeogene compression-related faulting in eastern Baffin Bay was probably a consequence of the same overall plate movements which also caused the Eurekan tectonic phase in North Greenland and Ellesmere Island. Portions of the large ridge structures likely contain block-faulted and post-rift Cretaceous sedimentary rocks later compressed into ridges such as the Melville Bay Ridge and the Kivioq Ridge (Figs 2-4). During the Palaeogene, flood basalts and other volcanic rocks developed in the West Greenland Volcanic Province and probably also in the Kivioq West volcanic area (Fig. 4). Paleocene-Eocene volcanic rocks cover parts of the Cretaceous basins such as in the Nuussuaq Basin (Dam et al. 2009; Larsen et al. 2015). Samples of flood basalt from the Delta-1 well offshore central West Greenland (Fig. 1) were dated to $c$. 50-56 Ma (Nelson et al. 2015). Sedimentary geometries suggesting basin-floor fan deposits were formed during the late Eocene to Oligocene in mega-unit $\mathrm{D}$, above horizon E1 (Fig. 2), presumably related to the Eurekan compressive phase. This was followed by more passive infilling of the remnant rift basins lasting until middle Miocene (horizon
D1; Fig. 2). During the late Miocene to Pliocene, large contourite drift- and mass-transport systems (e.g. mega-slides) developed in Baffin Bay within mega-units B and C (between horizons B1 and D1; Fig. 2) (Knutz et al. 2015). The final phase of basin development is characterised by major progradation of the West Greenland shelf towards southwest (mega-unit A between A1 and B1; Fig. 2) mainly as a result of trough-mouth fans formed by late Pliocene-Pleistocene glaciations (Knutz et al. 2015).

Interpretation of seismic facies and attributes has identified a number of amplitude anomalies (bright events) and vertical disturbances (chimney structures) on seismic data over structural highs in the Cenozoic section. Some of the features could relate to upwards migration of fluids and possible active petroleum systems. Some of the source rocks that produce oil seeps in the Nuussuaq Basin and equivalent sources in west Baffin Bay could occur in basins of eastern Baffin Bay (Bojesen-Koefoed 2011). Large structural crests within Cretaceous sections occur close to deep basins (Fig. 2), and some of the structures may include potential traps for hydrocarbons, given the right conditions. 
The updated mapping and new interterpretation in this study have improved the large-scale mapping of the structures and basins of the eastern Baffin Bay region, outlining a prospectivity potential and also pointing to uncertainties and risks that require future clarification.

\section{Acknowledgements}

The study was co-financed by the Ministry of Mineral Resources (Government of Greenland) and GEUS. The constructive comments and improvements of the manuscript from referees Lynn Dafoe and Christopher Harrison are appreciated and acknowledged. TGS-NOPEC Geophysical Company ASA is acknowledged for permission to publish the seismic section.

\section{References}

Altenbernd, T., Jokat, W., Heyde, I. \& Damm, V. 2014: A crustal model for northern Melville Bay, Baffin Bay. Journal of Geophysical Research-Solid Earth 119, 8610-8632.

Bojesen-Koefoed, J.A. 2011: West Greenland petroleum systems. An overview of source rocks and oil seepages and their implications for offshore petroleum exploration. Danmarks og Grønlands Geologiske Undersøgelse Rapport 2011/42, 49 pp.

Bojesen-Koefoed, J.A., Christiansen, F.G., Nytoft, H.P. \& Pedersen, A.K. 1999: Oil seepage onshore West Greenland: evidence of multiple source rocks and oil mixing. In: Fleet, A.J. \& Boldy, S.A.R. (eds): Petroleum geology of Northwest Europe: Proceedings of the 5th conference. Geological Society, London, 305-314.

Brent, T.A., Chen, Z., Currie, L.D. \& Osadetz, K. 2013: Assessment of the conventional petroleum resource potential of Mesozoic and younger structural plays within the proposed National Marine Conservation Area, Lancaster Sound, Nunavut. Geological Survey of Canada, Open File 6954, 40 pp.

Dam, G., Pedersen, G.K., Sønderholm, M., Midtgaard, H., Larsen, L.M., Nøhr-Hansen, H. \& Pedersen, A.K. 2009: Lithostratigraphy of the Cretaceous-Paleocene Nuussuaq Group, Nuussuaq Basin, West Greenland. Geological Survey of Denmark and Greenland Bulletin 19, $171 \mathrm{pp}$.

Damm, V. 2010: The expedition of the research vessel "Polarstern" to the Arctic in 2010 (ARK-XXV/3). Berichte zur Polar- und Meeresforschung (Reports on Polar and Marine Research) 621, 234 pp. Alfred Wegener Institut für Polar- und Meeresforschung, Germany, http://hdl.handle.net/10013/epic.36297.
Dawes, P.R. 1997: The Proterozoic Thule Supergroup, Greenland and Canada: history, lithostratigraphy and development. Geology of Greenland Survey Bulletin 174, 150 pp.

Gregersen, U., Hopper, J.R. \& Knutz, P.C. 2013: Basin seismic stratigraphy and aspects of prospectivity in the NE Baffin Bay, Northwest Greenland. Marine and Petroleum Geology 46, 1-18.

Knutz, P.C., Hopper, J.R., Gregersen, U., Nielsen, T. \& Japsen, P. 2015: A contourite drift system on the Baffin Bay-West Greenland margin linking Pliocene Arctic warming to poleward ocean circulation. Geology 43, 907-910.

Larsen, L.M., Pedersen, A.K., Tegner, C., Duncan, R.A., Hald, N. \& Larsen, J.G. 2015: Age of Tertiary volcanic rocks on the West Greenland continental margin: volcanic evolution and event correlation to other parts of the North Atlantic Igneous Province. Geological Magazine 153(3), 487511, http://dx.doi.org/10.1017/S0016756815000515.

MacLean, B. \& Williams, G.L. 1983: Geological investigations of Baffin Island Shelf in 1982. In: Current Research, Part B, Geological Survey of Canada, Paper 83-1B, 309-315.

Nelson, C.E., Jerram, D.A., Clayburn, J.A.P., Halton, A.M. \& Roberge, J. 2015: Eocene volcanism in offshore southern Baffin Bay. Marine and Petroleum Geology 67, 678-691.

Oakey, G.N. \& Chalmers, J.A. 2012: A new model for the Paleogene motion of Greenland relative to North America: Plate reconstructions of the Davis Strait and Nares Strait regions between Canada and Greenland. Journal of Geophysical Research 117, 1-28.

Reid, I. \& Jackson, H.R. 1997: Crustal structure of northern Baffin Bay: Seismic refraction results and tectonic implications. Journal of Geophysical Research 102, 523-542.

Rolle, F. 1985: Late Cretaceous - Tertiary sediments offshore central West Greenland: lithostratigraphy, sedimentary evolution, and petroleum potential. Canadian Journal of Earth Sciences 22, 1001-1019.

Suckro, S.K., Gohl, K., Funck, T., Heyde, I., Ehrhardt, A., Schreckenberger, B., Gerlings, J., Damm, V. \& Jokat, W. 2012: The crustal structure of southern Baffin Bay: implications from a seismic refraction experiment. Geophysical Journal International 190, 37-58.

Whittaker, R.C., Hamann, N.E. \& Pulvertaft, T.C.R. 1997: A new frontier province offshore northwest Greenland: structure, basin development, and petroleum potential of the Melville Bay area. American Association of Petroleum Geologists Bulletin 81, 978-998.

Authors' address
Geological Survey of Denmark and Greenland, Øster Voldgade 10, DK-1350 Copenhagen K, Denmark; E-mail: ug@geus.dk 